Western University

Scholarship@Western

Aboriginal Policy Research Consortium International (APRCi)

$12-5-2007$

\title{
Aboriginal and Non-Aboriginal Australia: The Dilemma of Apologies, Forgiveness, and Reconciliation
}

David Mellor

Deakin University

Di Bretherton

University of Melbourne

Lucy Firth

University of Melbourne

Follow this and additional works at: https://ir.lib.uwo.ca/aprci

Part of the Psychiatry and Psychology Commons

Citation of this paper:

Mellor, David; Bretherton, Di; and Firth, Lucy, "Aboriginal and Non-Aboriginal Australia: The Dilemma of Apologies, Forgiveness, and Reconciliation" (2007). Aboriginal Policy Research Consortium International (APRCi). 437.

https://ir.lib.uwo.ca/aprci/437 
This article was downloaded by: [University of Western Ontario]

On: 20 December 2012, At: 11:22

Publisher: Routledge

Informa Ltd Registered in England and Wales Registered Number: 1072954

Registered office: Mortimer House, 37-41 Mortimer Street, London W1T 3J H, UK

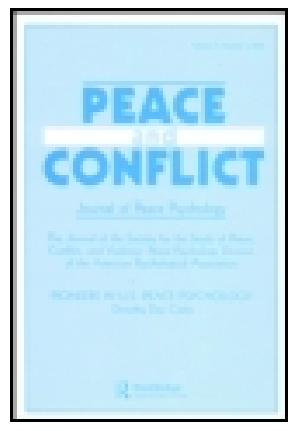

\section{Peace and Conflict: J ournal of Peace Psychology}

Publication details, including instructions for authors and subscription information:

http:// www. tandfonline.com/loi/ hpen20

\section{Aboriginal and Non-Aboriginal Australia: The Dilemma of Apologies, Forgiveness, and Reconciliation}

David Mellor ${ }^{a}$, Di Bretherton ${ }^{b} \&$ Lucy Firth ${ }^{b}$

${ }^{a}$ Deakin University,

${ }^{b}$ University of Melbourne,

Version of record first published: 05 Dec 2007.

To cite this article: David Mellor , Di Bretherton \& Lucy Firth (2007): Aboriginal and Non-Aboriginal Australia: The Dilemma of Apologies, Forgiveness, and Reconciliation, Peace and Conflict: J ournal of Peace Psychology, 13:1, 11-36

To link to this article: http:// dx. doi. org/ 10.1080/ 10781910709336766

\section{PLEASE SCROLL DOWN FOR ARTICLE}

Full terms and conditions of use: http://www.tandfonline.com/page/termsand-conditions

This article may be used for research, teaching, and private study purposes. Any substantial or systematic reproduction, redistribution, reselling, loan, sub-licensing, systematic supply, or distribution in any form to anyone is expressly forbidden.

The publisher does not give any warranty express or implied or make any representation that the contents will be complete or accurate or up to date. The accuracy of any instructions, formulae, and drug doses should be independently verified with primary sources. The publisher shall not be liable for any loss, actions, claims, proceedings, demand, or costs or damages 
whatsoever or howsoever caused arising directly or indirectly in connection with or arising out of the use of this material. 


\title{
Aboriginal and Non-Aboriginal Australia: The Dilemma of Apologies, Forgiveness, and Reconciliation
}

\author{
David Mellor \\ Deakin University \\ Di Bretherton and Lucy Firth \\ University of Melbourne
}

\begin{abstract}
This article presents a qualitative study of the indigenous Australian perspective on reconciliation with nonindigenous Australia, with a focus on the role of an apology for the oppression and violence perpetrated by nonindigenous Australians, and forgiveness on the part of indigenous Australians. A brief historical analysis of the relationship between Aborigines and waves of settlers is presented to demonstrate the extent of the wrong that was perpetrated against Aborigines and the need for social as well as practical reconciliation in the current context. It is argued that negotiated forgiveness is a concept that is pertinent to the discussion of reconciliation, because it requires a dialogue between the parties and ultimately for the wrongdoer to accept accountability and responsibility for offending actions, thereby opening the door for forgiveness and, ultimately, possible reconciliation. It is suggested that a first step in the required reconciliation dialogue is an apology, but the issue of who should give and receive an apology is a complex one. The issue of who should forgive and who should be forgiven is shown to be similarly complex. Qualitative analysis of interview data from 10 participants indicated that at this point in time, forgiveness might not be salient to the indigenous population, whose primary focus is more on the matter of an apology. This suggests that negotiated forgiveness and reconciliation will remain elusive goals until the matter of an apology is resolved.
\end{abstract}

Reconciliation requires both an apology and forgiveness. Together, an apology and forgiveness pave the way to healing and reconciliation, allowing disrupted or sev-

Correspondence should be addressed to David Mellor, School of Psychology, Deakin University, Burwood 3125, Australia. E-mail: mellor@deakin.edu.au 
ered relationships to begin anew. Forgiveness is one of the least understood but necessary acts required to fully break a cycle of violence (Hartwell, 1999), whereas an apology is an act of speech that seeks and facilitates forgiveness (Tavuchis, 1991). Reconciliation, with both an apology and forgiveness, is highly relevant to Australia, where the violence of the colonial and postcolonial past has left the indigenous population severely disadvantaged and encumbered with unhealed wounds.

Recent discussions in Australia have centered on the pain experienced by the indigenous community ${ }^{1}$ as a result of the removal of children from families over an extended period (1910-1970) and the need for an apology or other actions by the nonindigenous community. However, what seems to be missing is any discussion of the possible response of the indigenous community to these actions, particularly its capacity and willingness to enter into forgiveness.

In this article we report on a qualitative study that investigated the neglected indigenous perspective on reconciliation, with a focus on the role of an apology and forgiveness. To provide some understanding of the complexity of the current situation, we begin with a brief review of the background to the need for reconciliation in Australia and an examination of the stalemate in the process that has arisen. We then explore the role of forgiveness and apologies in reconciliation and the relation between them in the Australian context before presenting our study and its findings.

\section{SOCIAL AND HISTORICAL BACKGROUND}

\section{Current Social and Economic Conditions}

In May 1997, the Australian Human Rights and Equal Opportunity Commission's National Inquiry into the Separation of Aboriginal and Torres Strait Islander Children From Their Families released its findings in a report known as Bringing Them Home. This report documented the harrowing stories of children, often from a mixed racial background, who, between the period of from 1910 to 1970, were removed from their Aboriginal families and placed into institutions or other forms of care. The rationale behind this removal was that they should be brought up to "White ways," but in many cases the care they received was punitive and abusive. As many as 1 in 10 Aboriginal children were taken away from their families, with the trauma of forced separation damaging not only the children but also their fami-

\footnotetext{
${ }^{1}$ The term indigenous refers to Aborigines and Torres Straight Islanders. The terms Aborigines and Aboriginal as used in this article refer to people and cultures from the Torres Straight Islands as well as Aborigines.
} 
lies and, more broadly, Aboriginal communities and cultures. The removed children are commonly referred to as the "Stolen Generations."

Although the policy of removing children was implemented in the past, a case can be made that colonial and postcolonial oppression and structural violence continue to occur, with the current situation of Aboriginal people being deplorable. This population of 410,000 people, or $2.2 \%$ of the population (Australian Bureau of Statistics, 2002a), remains the most disadvantaged group in Australian society (Hunter, 2000). The present-day disadvantaged position of Aboriginal people is reflected in the statistics relating to matters of health, employment, education, judiciary, and housing (Australian Bureau of Statistics, 2001, 2002a, 2002b, 2002c). Indigenous infant mortality rates are more than twice those of the general population, and life expectancy of indigenous people is between 19 and 20 years lower than it is for other Australians. The indigenous unemployment rate is three times the national average, and family incomes are only two thirds those of nonindigenous families. The indigenous imprisonment rate is approximately 14 times that of the nonindigenous population. There have also been high rates of deaths in custody that have not declined even though this issue has been the subject of a Royal Commission that provided strong and extensive recommendations about the treatment of indigenous prisoners (Cunneen \& McDonald, 1997).

Despite progress over the past few decades, there is much work to be done by way of what the current government terms "practical reconciliation." However, practical reconciliation fails to address the full impact of the colonial and postcolonial history of dispossession, structural violence, and racism. To provide a context for understanding the need for a more "social" reconciliation in Australia, it is necessary to explore this history, albeit briefly. For simplicity, we present this history in a series of three stages, with a fourth stage proposed for the future.

\section{Stage 1: Invasion and Dispossession}

Before White people arrived in Australia, the continent was occupied by as many as 750,000 indigenous people who lived in approximately 700 different groups (White \& Mulvaney, 1987). Each group had its own territory, political system, laws, and dialect. There were many commonalties among the groups in terms of their culture and belief systems. Despite this, when the continent of Australia was claimed by England, it was regarded by the early settlers as terra nullius, or empty land, and as having no ownership, culture, or law. Yarwood and Knowling (1982) documented how, based on prevailing philosophies and religious doctrine, the settlers considered themselves to be of a superior species to the indigenous population. The disdain for the indigenous population manifested in many "frontier wars" and massacres. In 1828, for example, up to 300 Aborigines were killed at Waterloo Creek north of Sydney (Yarwood \& Knowling, 1982). Such massacres continued into the 20th century, with, for example, a 1928 Royal Commission finding that at 
least 11 Aborigines had been systematically tracked down, shot, and burned by police in response to the killing of a settler in 1927 in the East Kimberley region of Western Australia (Green, 1995).

Recently, there have been discussions about whether such treatment of indigenous people by successive waves of nonindigenous early settlers falls within the realm of genocide. Reynolds (2001) reviewed several events that led to significant declines in the indigenous population, and although he uncovered ample evidence of "genocidal intent" at the local level in many cases, the task of demonstrating official intent is much more difficult. Notwithstanding the factual evidence, few people, even in Australia, realize or acknowledge the extent of the devastation that White settlers and their descendants inflicted on Aboriginal people. It is also important to note that some others (e.g., Windschuttle, 2002) have even suggested that this "black-arm band" view of history is built on myths.

\section{Stage 2: Protection and Assimilation}

From early in the 20th century, a phase of forced, but limited, assimilation and "protection" of Aboriginal people commenced. In various states, Native Welfare Departments were established to supervise the lives of the indigenous people. Such supervision, although on the one hand offering protection, violated the human rights of Aboriginal people as they were denied access to many facilities available to non-Aboriginal people and suffered numerous restrictions in their activities.

This phase has been described by van Krieken (1999) as one in which welfare intersected with violence. Perhaps the most significant demonstration of this violence was the collusion between state and church to remove mainly part-Aboriginal children from their parents so that they might be "better" cared for. Underlying these practices was the belief that the indigenous population would eventually be eliminated. It was believed that the full-blood members of the population would naturally die out, and the aboriginality could be "bred out" of the part-Aboriginal population. In the meantime, it was thought that the part-Aboriginal people should be dissociated from their indigenous background and assimilated into the White population. The Australian Human Rights and Equal Opportunity Commission (1997) report described this practice as a gross violation of the human rights of inigenous people and described the policies in terms of attempted genocide. The detrimental impact on individual, family, and cultural health has been well documented (Australian Human Rights and Equal Opportunity Commission, 1997; Bretherton \& Mellor, 2006).

\section{Stage 3: The Struggle for Self-Determination}

In the late 19th century, a small number of individuals advocated for Aboriginal rights, and in the 1930s there were some protests by activists seeking better condi- 
tions for Aborigines. However, it was not until after the Second World War that any semblance of a national conscience in relation to Aborigines began to emerge. Even so, Aboriginal people had to wait until 1967 before a national referendum, supported by a huge majority ( $>90 \%)$, acknowledged their citizenship. In practice, though, citizenship did not lead to equal status. Although in theory it allowed Aborigines to enter cinemas, for example, and to vote at elections if they wished (voting is now compulsory, as it is for other Australians), in the context of history, the granting of citizenship was merely a constitutional milestone in the continuing struggle for Aborigines to have their identity and rights affirmed.

As part of the 1967 referendum outcome, Aboriginal affairs were transferred from the states to the federal government, which reduced the piecemeal nature of the system that had governed indigenous people's lives. However, they were still unable to attain secure title to traditionally occupied land because their right of occupation depended on whether it was desired for other purposes. The issue of land rights is now a predominant issue in the Aboriginal struggle. Not only is it an economic issue, it is also a cultural, spiritual, and identity issue for Aboriginal people.

To summarize the preceding three stages, Aboriginal people have suffered severely as a result of White settlement, which brought the introduction of new diseases, dispossessed them of their land, and destroyed many aspects of their culture. Dispossession and oppression have resulted in social disintegration, economic marginalization, unacceptable health standards, and lack of opportunity. Even today, nearly 30 years after the recognition of Aborigines as citizens, they still experience pervasive, overt, and covert racism in their daily lives (Mellor, 2003).

\section{Stage 4: Proposal for Negotiated Reconciliation}

Aboriginal activist Lillian Holt (personal communication, July 2003) advocates the need for a fourth stage that differs from the previous three in that it should not focus on Aboriginal people as "the problem." Rather, it should involve those who are non-Aboriginal engaging in an interrogation of their own "Whiteness" and in coming clean not only about the past but also about the privileged status it allows them to occupy in the present. This view echoes the sentiment expressed by former Prime Minister Paul Keating in his 1992 speech to launch the International Year of the World's Indigenous People when he suggested that the problem in Australia began with "us non-Aboriginal Australians" and "our ignorance and our prejudice." The issue now is how to address the past and to move to a future in which such "negotiated reconciliation" would be possible.

\section{Redressing the Past}

Treaty or reconciliation? One attempt to negotiate a path to redress the brutality embedded in the slowly emerging understanding of the history of White set- 
tlement was the proposal for a treaty that was put forward in the years of the Hawke government (1983-1992). However, a treaty would raise many complexities, one of which was suggested by current Prime Minister John Howard who has argued that the idea is absurd because a nation cannot make a treaty with itself. In the face of these complexities, the proposal for a treaty has been put on the back burner as another less difficult, softer approach, officially designated reconciliation has been initiated.

The word reconciliation is a diplomatic one that can mean different things to different people. For those at the more conservative end of the political spectrum, it can mean the need to settle disputes and resolve uncertainty (e.g., about the ownership of land), even at the cost of diminishing Aboriginal rights. The use of a word such as reconciliation allows discussions to skate over the depths of division in the community and to contain disagreements beneath a veneer of apparent progress and accord. Indeed the current government's focus on practical reconciliation to the exclusion of social or intergroup reconciliation has done just that. Rather than address relationship issues, practical reconciliation focuses on issues such as housing, health, and education. Although it is obviously important to address these issues, the divisions between the nonindigenous and indigenous communities remain unaddressed.

The need for an apology. One striking aspect of the recent reconciliation debate has been that the focus has centered largely on the role of the nonindigenous community in the process now that the indigenous community has been given the opportunity to present its historic narrative through the National Inquiry into the Separation of Aboriginal and Torres Strait Islander Children From Their Families. The public discussion has been mainly about what acts on the part of the government and nonindigenous community should be undertaken, on the assumption that reconciliation will (almost automatically) follow. Generally, some form of apology has been the dominant theme in such discussions.

Indeed, the National Inquiry into the Separation of Aboriginal and Torres Strait Islander Children From Their Families called for governments, churches, police forces, and welfare agencies involved in forced removals to apologize to Aboriginal Australians. When the first official Convention of Reconciliation met, in the same month in which the Bringing Them Home report was released, the large audience of Aboriginal and non-Aboriginal people expected Prime Minister John Howard to use the occasion of his opening speech to deliver an apology on behalf of the nation. Although he acknowledged the blemish of the past and expressed personal regret, he stated, "Australians of this generation should not be expected to accept guilt and blame for past actions and policies over which they have no control" (cited by Gooder \& Jacobs, 2000, p. 230). His speech was understood to be a refusal to apologize, and angry members of the audience turned their backs in protest. Since this time, the inability or unwillingness of the federal government to 
apologize has stalled the reconciliation process on what Gooder and Jacobs termed "the border of the unsayable." The postcolonial apology is, they eloquently stated, "an utterance located on the border of that which feels absolutely necessary and that which feels too risky to say" (p. 231).

The Australian Aboriginal and Torres Strait Islander Commission also argued that an apology is an elementary condition of reconciliation in Australia, but what would constitute a proper apology? Gooder and Jacobs (2000) have suggested that a proper apology has to express sincere sorrow and regret and to involve promising not to repeat the offense. This assumes that the offense is in the past, and, as demonstrated earlier, such an assumption is problematic in the Australian context. In addition, a number of other issues arise. For example, who can apologize for whom, and would the apology be just for the Stolen Generations, or would the apology be for the whole 200 years of colonial and postcolonial oppression? The Prime Minister's refusal to apologize to Aboriginal people for the Stolen Generations was not so much a lack of regret at the wrongs of the past but rather his disclaimer of national responsibility. That is, what was expected but not forthcoming was a national apology delivered by the national leader. The flurry of community and organizational responses to the National Inquiry into the Separation of Aboriginal and Torres Strait Islander Children From Their Families has not compensated for, but rather has served to highlight, the absence of an official apology.

Forgiveness. What has not been considered in the public discussions is the role of indigenous people's forgiveness and its relation to apology and reconciliation. McClernon, Cairns, Lewis, and Hewstone (2003) described intergroup forgiveness as the necessary forerunner of reconciliation. However, according to Smedes (1998), the process of intergroup forgiveness remains a theoretical quandary, and the understanding of this process in the reconstruction of postconflict societies is as yet poorly developed (Hartwell, 1999). There is even a lack of agreement as to what forgiveness is (McCullogh, Pargament, \& Thoresen, 2000), with Tavuchis (1991) describing it as crucial in the apologetic equation yet mysterious, unpredictable, and not adequately addressed or formulated. Among the unanswered questions, he asked "What moves the offended party to forgive, in historical and cross-cultural terms, what is deemed forgivable and unforgivable?" (p. 122). To confound matters further, Hartwell appropriately noted that when forgiveness enters into the discussion it implies that extreme suffering has been experienced by one party at the hands of another. How then can forgiveness be possible when, as in Australia, the acts of violence that caused the suffering have occurred between the same people attempting to rebuild the society?

In one approach to understanding forgiveness, Andrews (2000) contrasted negotiated forgiveness with forgiveness that is unilateral. Unilateral forgiveness is not based on encountering, understanding, and accepting the wrongdoer but is an unconditional gift. When a person forgives unilaterally, noted Enright and the Hu- 
man Development Study Group (1994), "he or she seeks nothing from the other" (p. 69). There is some evidence that this type of forgiveness benefits the person who does the forgiving (Brush, McGee, Cavanagh, \& Woodward, 2001; Kaminer, Stein, Mbanga, \& Zungu-Dirwayi, 2001) but little evidence as to the impact of this type of forgiveness on the forgiven person or the community. Because reconciliation is contextual and relational, the model of negotiated forgiveness has greater relevance to national reconciliation processes.

Negotiated forgiveness involves a dialogue between the wrongdoer and the wronged. It involves the idea of accountability, of the wrongdoer taking responsibility for the offending actions. "Setting the record straight—acknowledging that wrongdoing has occurred-is not only a historical but a moral end," suggested Andrews $(2000$, p. 82). This view of forgiveness is dialectical, calling for both reaching out to others and looking into oneself.

An apology may be the first step in the process of negotiated forgiveness. By offering a sincere and timely apology, the wrongdoer can communicate that he or she respects the other, is prepared to own up and be accountable, will take responsibility for the offense, and will try to make reparation and not repeat the offense. The emotional requirement is to show genuine remorse that the offense has damaged a relationship that is valued. By taking this first step, the wrongdoer makes it possible for the wronged party to forgive. According to Enright and the Human Development Study Group (1991), this involves the wronged party willingly abandoning its right to resentment, negative judgment, and indifferent behavior toward the perpetrator and fostering the undeserved qualities of compassion, generosity, and even love toward him or her (p. 123). However, Andrews (2000) cautioned that there is no moral obligation on the latter to accept an apology; indeed, the wronged may, for a variety of reasons (such as that the offense is too heinous or that the effects flow on to others) feel a duty to withhold forgiveness. Further, even if there is an apology and forgiveness ensues, reconciliation may not necessarily occur (Enright \& Zell, 1989; Worthington, 1998).

These theories of forgiveness are, in the main, related to interpersonal forgiveness. As has been pointed out by others (e.g., Hartwell, 1999; McCullough et al., 2000), it is by extrapolation that they are applied to intergroup situations. It is clear that in this context, forgiveness is multidimensional as it provides the means of launching a new beginning by rebuilding social, political, and economic structures on a national level (Hartwell, 1999) by attending to "moral truth, history and the human benefits that flow from the conquest of enmity" (Shriver, 1995, p. 9). We have argued elsewhere (Mellor \& Bretherton, 2003) that the issues of moral truth and history are particularly problematic in Australia, as not only do the indigenous and nonindigenous populations share different social memories, but the means of recording, transmitting, and celebrating aspects of history are at considerable variance. 
In the Australian context, a further set of questions relates to who should forgive and who should be forgiven. Although there are government-appointed indigenous bodies that advise the government on the assumption that they represent the indigenous population, the target population is varied and has been affected in different ways by European colonization. ${ }^{2}$ Many families were torn apart and their communities and cultures significantly disrupted by the removal of children; other communities have managed to retain more of their traditions and identity and to keep their cultures largely intact. Many communities were driven from their traditional land, whereas others have been able to retain access and rights to it. Who, from which of these communities, will forgive the nonindigenous population in relation to the brutal events of history?

On the other side of the equation is that group of people who might be forgiven. Many following the Prime Minister would argue that the present generations, even those who are descendants of the original waves of settlers, were not directly involved in the history described and therefore have nothing for which to apologize or for which to be forgiven. However, this ignores the fact that all present-day nonindigenous Australians, including the $24 \%$ born overseas and the $27 \%$ who have at least one parent born overseas (Australian Bureau of Statistics, 2002a), have benefited directly or indirectly from the dispossession of the indigenous people and are currently occupying the cultural and physical space that originally belonged to the indigenous people. Although new immigrants are usually seen as being outside the reconciliation debate, Poole (1999) argued that those who move to and live in a multicultural society are obliged to accept the national identity. This national identity involves not just a sense of place but a sense of history, which makes up the national memory. This history cannot be disavowed, and it comes with rights and responsibilities. Part of this responsibility is to come to terms with the Australian past; this is morally an inescapable component of being a (nonindigenous) Australian.

\section{THIS STUDY}

The purpose of this study was to elicit Aboriginal viewpoints on the twin processes of apology and forgiveness in reconciliation. A search of the transcripts from previous research on Aboriginal views of the relationship with non-Aboriginal people and the experience of racism (Mellor, 2003, 2004) found that Aboriginal people did not spontaneously invoke matters of apologies, forgiveness, and reconciliation

\footnotetext{
${ }^{2}$ The Australian government applies three criteria to determine who should be identified as indigenous: An Aborigine or Torres Strait Islander is a person (a) of Aboriginal or Torres Strait Islander descent, (b) who identifies as an Aborigine or Torres Strait Islander, and (c) is accepted as such by the community in which he or she lives.
} 
into their discourse. This viewpoint is missing from the wider discussion of reconciliation yet needs to be incorporated into such discussion.

We chose a qualitative method, specifically semistructured interviews, as a means of data collection based on a number of considerations. First, not only within the general population but also within the research community, the issue of reconciliation is something of a novelty, and the matter of forgiveness has not entered the discussion. The indigenous perspective in particular is largely unknown. The foci of our study, including the matters raised in the previous discussion, were not suited to quantification, as we aimed to access the contextual richness of the participants' views. Second, the oral tradition is the preferred means of communication among indigenous people; any attempts to use a quantitative approach might have caused discomfort for our participants, especially in view of the fact that due to lack of educational opportunities, many indigenous people have limited literacy skills. Third, we are cognizant that Aboriginal people are a small and much-studied minority and, as we have noted elsewhere (e.g., Mellor, 2003, 2004), there is an extreme scepticism among Aboriginal Australians about the usefulness of any research involving them. Dudgeon and Oxenham (1989) drew on Nobles's (1980) concept of "scientific colonialism" to explain this. They suggested that many indigenous Australians feel that research conducted by nonindigenous Australians about them is simply another means of exploitation and that few benefits have flowed back into indigenous communities. Any research should be collaborative and rely on personal engagement with participants. This is best achieved through conversational techniques that focus on listening to their concerns. Finally, being researchers from the nonindigenous community, framing our questions without providing the means for elaboration and clarification of responses might have led to misrepresentation of the participants' perspectives.

\section{METHOD}

\section{Participants}

Ten indigenous people from disparate areas of Australia were interviewed. The first 5 participants came from an isolated area in northwest Australia, whereas the remaining participants came from a region in the more densely populated southeast corner of the continent. There were 5 adult men and 5 adult women in the sample. As it is sometimes insensitive to ask indigenous people their age, we did not seek this information. Snowball sampling was used, with the initial interviewees being asked to suggest subsequent informants who would be in a position to contribute their views. Snowball sampling is a useful approach when there is difficulty in identifying or accessing members of the population, such as when there is a clandestine group (Robson, 1993). The requirements for participation were that 
the individual identify him or herself as indigenous Australian and, after being informed of the nature and requirements of the study, be agreeable to participate on a voluntary basis. All persons we approached agreed to participate.

\section{Materials}

We interviewed participants using a semistructured questionnaire that included questions about the need for an apology, the nature of an apology, and the requirements for forgiveness. The questions are shown in detail in Table 1 .

\section{Procedure}

Following Finch's (1993) suggestions on how to avoid relative power relationships influencing interviews between researchers from the dominant group and participants from a group that has suffered oppression, the structure of the interviews was limited to open-ended questions and the interviews were conducted on the participants' own "territory" (i.e., at community centers and meeting places or in their homes). Interviews were undertaken by local people, one of whom was Aboriginal. With the participants' permission, the interviews were recorded on audiotape for later transcription. This allowed participants to talk informally in a relaxed atmosphere. Each interview began with the following introduction:

Today I would like to ask you some questions about reconciliation. I am working with some people at Melbourne and Deakin Universities who have been researching in this area and also running reconciliation programs for people in Melbourne. There are no right or wrong answers to these questions. We just want to find out what Aboriginal people think about these things.

I would like to tape-record your answers. We don't need to record your name or anything else about you, but we would like you to say at the beginning of the interview that you are talking to me voluntarily and have no objections to me recording your answers. This is just the normal procedure I have to follow. Is that all okay with you?

The interviewer then proceeded to ask the questions, with permitted prompts, as shown in Table 1.

\section{RESULTS}

After transcription, the interviews were analyzed for themes. Following the procedures outlined by Colaizzi (1978) for the analysis of phenomenological data, all protocols (transcripts) were read to provide the researchers with an overall familiarity 
TABLE 1

Interview Questions and Probes

\begin{tabular}{|c|c|}
\hline Question & Permitted Probes \\
\hline What does reconciliation mean to you? & How important is it for you? \\
\hline $\begin{array}{l}\text { One of the big issues about reconciliation is } \\
\text { about an apology to the aboriginal } \\
\text { community for all the things that happened } \\
\text { in the past. Do you think we need an } \\
\text { apology? }\end{array}$ & Tell me why. \\
\hline Who should make the apology? & $\begin{array}{l}\text { How important is it for the government to } \\
\text { apologize? } \\
\text { Some people say that groups like churches, } \\
\text { police forces, and welfare agencies should } \\
\text { make an apology, because some of them were } \\
\text { involved in the removal of kids for example. } \\
\text { Do you agree with that? } \\
\text { Do you think there are other people or groups } \\
\text { who should apologize? } \\
\text { How about other non-Aboriginal Australians: Do } \\
\text { you think they should make an apology too, as } \\
\text { individuals? }\end{array}$ \\
\hline $\begin{array}{l}\text { In your opinion, which apology will have the } \\
\text { greatest significance for the Aboriginal } \\
\text { Australians as a people? }\end{array}$ & $\begin{array}{l}\text { Which one would have the greatest significance } \\
\text { for you as a person? }\end{array}$ \\
\hline $\begin{array}{l}\text { Is an official national apology a basic } \\
\text { condition of reconciliation between } \\
\text { Aboriginal and non-Aboriginal Australians } \\
\text { in your opinion? }\end{array}$ & \multirow[t]{4}{*}{$\begin{array}{l}\text { In what terms should such a national apology be } \\
\text { formulated and what message should it } \\
\text { convey? }\end{array}$} \\
\hline $\begin{array}{l}\text { What should non-Aboriginal Australians } \\
\text { apologize for? }\end{array}$ & \\
\hline To whom should an apology be addressed? & \\
\hline $\begin{array}{l}\text { If an apology isn't given, how can } \\
\text { reconciliation between Aboriginal and } \\
\text { non-Aboriginal Australians be achieved? }\end{array}$ & \\
\hline $\begin{array}{l}\text { For Aboriginal Australians to be able to } \\
\text { forgive White Australians, what would } \\
\text { need to happen? }\end{array}$ & Is there anything else that would need to happen? \\
\hline
\end{tabular}

with them. Then, phrases or sentences that directly related to the phenomena under investigation (an apology and forgiveness) were extracted from each protocol and meanings formulated for them. The aggregated formulated meanings were organized into clusters of themes, as summarized in Table 2. These themes were then compared against the transcripts to ensure that they did not omit any aspect of the data or propose anything that was not implied in the data. Our summary of the outcome of our analysis is presented by way of extracts from the data. The extracts are illustrative of the views of the group that was interviewed. Given the small number 
TABLE 2

Themes Emerging From the Content Analysis

1. An apology is needed.

The non-Indigenous community must apologize to the Indigenous community

2. The apology needs to be broadly based.

It should

a. come from across the community, at the individual level.

b. be made official by the peak representatives of the population, the Prime Minister.

c. be additionally made by institutions involved in past structural and direct violence against Indigenous people.

3. The apology should relate to the multiple losses experienced by the Indigenous community.
a. family
b. culture
c. land
d. language

It should recognize that what was done
a. was wrong.
b. caused much individual and collective damage.
c. needs to be acknowledged and owned.

4. An apology may facilitate reconciliation.

5. Recent immigrants need to be involved in the apology as they also occupy Indigenous lands.

6. An apology would help non-Indigenous people understand the past.

of participants, it was not considered meaningful to give frequencies, analyze group differences, or suggest that the results represent the diversity of views of Aboriginal people. Despite these limitations, there was value in actually consulting with Aboriginal people and gaining a snapshot of "grassroots" thinking on the issue.

\section{An Apology Is Needed}

The interviewees were in agreement that there should be an apology. For example, 1 participant framed her view as follows: "They should apologize to us. They should have apologized in the first place, and started from the beginning to give the people back what they want." $(\mathrm{P} 4)^{3}$

\section{An Apology Needs to be Both Broadbased and Official}

Participants identified a need for the apology to be official and national. Responses to the question of who should apologize gave rise to suggestions such as the government, the Prime Minister, or a high official. For example, 1 participant (P9) argued that the apology should come from the "top down," via the parliament, whereas P1 said

\footnotetext{
${ }^{3}$ Participants were coded and are referred to here as P1, P2, and so on.
} 
Well, I suppose it would be the Prime Minister, seeing he is like top of the hierarchy or whatever. But, as long as, like I don't think it's important who makes it, as long as it's recognized as an official apology, sort of stuff. It could come from like some Jo Bloggs person living in the middle of nowhere. But if it's an official apology then it's recognized nationwide as that. It doesn't matter whose mouth it comes out of, as long as it's formal. ... A government apology that's what I think. Like because they're actually recognizing that the people that were put in charge, that were thought of as part of the same organization they are ... Yeah, but with the government, it's constantly there.

Other reasons for seeking an apology from the Prime Minister included that "this is where the power is" (P1) and therefore the apology would be more likely to have an impact, and "after all, he is our leader, isn't he?" (P6). "If done sincerely, an apology by the 'leader of the country' would be significant enough" (P9). Further,

If the government is obviously apologizing, it's going to make the people say "well if the government's apologizing there's got to be something wrong here." (P1)

One participant (P10) reflected that apologies from individuals might be more sincere but nonetheless felt that the Prime Minister should lead the way by apologizing first:

Well I think it would be most significant if it would be individuals. Yeah because then, like in a group you can say like sorry, but not really mean it. And there might be like some people that say sorry instead of all of them. Um yes the individual, well yeah. Well yeah, basically everyone looks up to him [Prime Minister] for like guidance and um, yeah if he says that and basically everyone else would like copy him.

However, although the overriding need for an official national apology was stressed, this did not negate the value of individual apologies:

Ah well, I think it would be good because then if there was like, everyone would be saying sorry and then that will make the Aboriginal people feel more like better, during the years go by. (P10)

The extent of individual apologies to date was acknowledged as important:

Many nonindigenous Australians have apologized by taking part in reforesting, and working with the people in the indigenous communities. (P8)

Similarly, apologies from institutions such as churches and the police forces were considered important: 
Yeah, because churches was the main one involved. They want to change the way of the Aboriginal people, you know. So what they did and how they structured the religion. (P10)

Then the police, they helped be involved with that. Yeah so they should. Um; you know, like if people would; if other people wanted to say, well yeah they could if they want. But um, basically the main groups that were involved with it. (P10)

These institutions could be excused to an extent because "they were just following the chain of command." However, "at the end of the day, they have their own conscience to say 'sorry' too" (P6). Interestingly, some participants also hold currently active organizations accountable and needing to apologize. For example, P7 suggested that in addition to the Prime Minister and state premier needing to apologize for the past, human service organizations and "those who help our young drink alcohol, and further minimize our race and rights" need to apologize. Similarly, P8 suggested that the apology should be given by "the powers that in their official capacity of office have continued to oppress indigenous Australians."

\section{An Apology Should Relate to the Multiple Losses Experienced by the Indigenous Community}

Given the history of the relationships between indigenous and nonindigenous Australians, it is interesting to consider which aspect is predominant in the minds of the participants as the major reason for the need for an apology. In this regard, each of the participants made reference to the Stolen Generations and indicated that they had been affected by removals of their mothers, fathers, brothers, or sisters. Participants suggested that for these acts, and the damage they have caused, an apology was needed. For example,

Well I am closest with my dad, he's been stolen. And yeah he was like; he told me his stories and all that, and how it affected him. And also how you know sorry would help him in a way. (P10)

Another respondent stressed that the apology was needed simply as a sign of recognition of the past:

That basically that they recognize what happened and that it was wrong sort of stuff. So yeah, if you tried to do that today oh, it would never happen. It wouldn't even be thought about. But um; yeah not saying like "we're sorry, we're sorry we did it," but "sorry you had to be put through that. Sorry you've lost your mother; sorry you've lost your child sort of stuff. Sorry you've like lost your culture, because that has totally gone." Well not totally gone, but a lot of it has gone. (P1) 
Other respondents stressed that the apology was needed so that responsibility for the past would be recognized:

Well I come from a family where my people have been taken. And ah, well, someone's got to answer for it, haven't they? You just can't go around and take someone whether they're White, Black or ... And think you're doing a good job. (P3)

Some form of national apology needs to recognize past wrongs and human rights violations ... the acknowledgement needs to look across the board at all the issues. (P8)

In essence, the message should "acknowledge [the past], own up, stand up and be counted, and say the truth ... It should be sincere, be true and mean "sorry"” (P6).

Another reason for an apology was to acknowledge the extent of damage caused by past actions:

Um; well firstly taking away the culture of Aboriginal people, and like trying to destroy their language and all that. So also like destroying the family and yeah, just mainly for those things. Well yeah they should say sorry that um, yeah they were taken away from their family and lost their culture because of that. (P10)

Imagine what it would have been like to lose traditions and language. (P7)

We are the traditional owners of this land, but what do we have to show for this? Nothing! (P6)

However, some of the reasons given for the need for an apology were embedded in the broader historical issues and collective memories:

Well like I said earlier, this country's been taken off the Aboriginal people. Before the White man came here, we owned this country, the whole lot. There wasn't just a little bit for that mob or this mob. We knew our boundaries but the country was earned. We were nomad; we walked from one area to the next. And with this compensation I think it should be handed back in parcels of land, and be recognized as Aboriginal people's land. And that's the only compensation that I'd see that would benefit the people. Not this money or anything else. (P3)

They were shooting our people, Black people. The Whites were on horses. They were walking with chains on their ankles and on their hands; they were treated really bad, our people. And they were on horseback. Our groups used to walk miles. (P4) 


\section{An Apology Could Facilitate Reconciliation}

For some, an apology was also seen as a precondition for reconciliation and moving forward:

Before this reconciliation thing comes about there's an apology. It's as simple as that and if they can't see that, well I don't know what they're doing then. (P3)

It's just one of those things, like where I reckon there should be an apology so the people can get it out of their way and get on with their lives. (P3)

Yes, an apology would mean a lot to me for past hurts. To move on and start afresh. The human heart needs to forgive. We need to reach out, each and every one of us. Re-con-cile! ... There has to be a starting point to all healing and for someone to stand up and say "I'm sorry," it's a beginning to put past hurts away and move on to healing ... Without an apology, it's hard to forget. It's human nature. The heart holds contempt until it mends, so without forgiveness, there is no reconciliation. (P6)

However, for others, although an apology was seen as being potentially helpful for the reconciliation process, it was not seen to be crucial:

It's not a basic condition, but we can get on with reconciliation without it. But it would play a pretty significant role if it did happen, sort of stuff. We don't need it to move on, but it would help. (P1)

On the other hand, one participant argued that

To acknowledge the past and apologize does not help those people who have lost family and loved ones by government intervention. Kinship ties were damaged and this does do little to appease a race who suffered death, illness (mental and physical) and ancestors whose language and dialogue have suffered. (P8)

Without an apology, though, this participant argued that

Reconciliation will be hard due to the fact that many tribes were wiped out by genocide, diseases and the traditions were suppressed. (P8)

Another participant took this even further. She suggested that

An apology would certainly be an acknowledgement of the wrongdoings by the government of the day. However, to a family or child who was part of the Stolen Generation, this apology would mean little. The impact that the Stolen Generation had on our people could never be rectified, and a "sorry" seems inadequate, particularly to a 
child who never saw his parents again or his family. To me, the "sorry" would need to be followed up with some benefit to those of our people who were stolen, and to the families who also suffered. (P9)

This participant went on to list a range of things the government would need to do, including increasing funding and providing basic services to indigenous communities, teaching the real story of Australia's history in schools, providing cross-cultural training for nonindigenous people, and addressing the health needs of indigenous people, elders, and youth.

\title{
Recent Immigrants Have a Role to Play
}

The conflict between Aboriginal and non-Aboriginal Australians is often defined using the historical polarities of the indigenous population and White settlers. Given the changing composition of Australian society, it was of interest to ask participants about their views of more recent immigrants. Should they also apologize? Respondents were strongly of the opinion that all nonindigenous people, including new immigrants, should apologize because, after all, they are "invading our space, taking over our thing" (P5).

Some comments suggested there was a strong sense of deprivation among the participants' own community and considerable resentment of the care accorded to asylum seekers, even though by many accounts this care is of an atrocious standard:

\begin{abstract}
Now they've got places like Port Headland, they got placed at Derby, Darwin. They have three meals a day, clean clothes and every bloody damn thing and they're picking up things off the bloody reef. They shouldn't be here. If we go over there we get shot ... On a boat, yeah, if they come here they have three meals a day, they've got a car, everything. They will come from Turkey, everywhere. You go in a prison here, on a weekend. All you'll see in there is Indonesian, Asian people imprisoned asylum seekers in there. What do they own? TV, mobile phone, every bloody damn thing. Have a look in the restaurants here. Look at the restaurants, the one here, the take-aways and that. Where are they from? Not here. From that way, across the sea. Now they're building here, where black people belong and own the land. (P6)
\end{abstract}

On the other hand, there were more measured responses that suggested an awareness of some common concerns and a need to include new arrivals in the process of reconciliation:

Um; well yeah in a way, because they're coming in to our way, yeah our ways and our country, and they should like recognize what happened. And yeah they also; and we also would need to accept them in the reconciliation. Because they're from a different group as well. (P10) 


\section{An Apology Would Help Nonindigenous People Understand the Past}

Respondents stressed what an apology would mean for non-Aboriginal rather than Aboriginal people. It would "Let people learn from the past, and have a conscience" (P7) and

Get them to understand the Aboriginal ways as well, so they can at least know a little of it and try and understand how we live. Um, and also if they have a little bit of understanding then they can get along better with us. (P10)

Respondents emphasized the need for greater knowledge of the past and greater understanding of the experience of Aboriginal people:

Well first I think it's got to be known to the Australian people what happened. And make it clear that, what's happened. And then everyone knows why this apology is, or what it's on about. Anyone can go and say sorry. But, if you don't know what they're saying sorry for. That's right, you know. (P3)

For nonindigenous people to understand the past, "wrongs" must be acknowledged. Missions and traditions and history [must] be sincerely understood by them. (P8)

\section{Another participant suggested}

There's people out there who still think it was right for them [indigenous children] to be taken away, sort of stuff. If it can be publicly acknowledged like that, then maybe you can get the message out somehow. Like, well, that actually was wrong. Something unfortunate did happen, sort of stuff. (P1)

A third argued that

they know its ANZAC day, ${ }^{4}$ what about the date when Cook $^{5}$ and them landed here. Everyone knows he landed here and they took over, but there wasn't anything about Aboriginal people getting shot or people taken away from their homes, and stuff like that. And so that's got to be told to people right throughout the country before they can accept this apology. You know the European people say well what are we saying sorry for? (P3)

\footnotetext{
${ }^{4}$ The Australian and New Zealand soldiers who died at Gallipoli in the First World War, and fallen members of the services generally, are remembered on ANZAC Day, a national holiday on April 25 each year

${ }^{5}$ James Cook, Captain of the Endeavour, is credited with "discovering" and claiming Australia on behalf of England in 1770.
} 
Finally, P8 implored nonindigenous Australians to

Stop ignoring that history has not [sic] had an impact; acknowledge that the hope of our people is in our children; teach aboriginal history and let the healing start for future generations.

Together with an apology, this understanding of the past was seen by some participants as a prerequisite for the possibility of forgiveness. For example, when asked what would be required for forgiveness to occur, P10 stated

Well, you would let them know, like, what has been done ... and also, like, get them to understand the Aboriginal ways as well, so they can at least know a little of it and try to understand how we live. If they have a little bit of understanding then they can get along a little better with us.

However, when asked about forgiveness directly, most participants seemed to avoid responding to the question by shifting the focus of the discussion. Others seemed to skate over the notion. For example, P1 stated that nonindigenous people need to open their eyes more and see what is actually happening. However, she went on,

As well as like the issue of forgiveness, there is also the issue of moving on sort of stuff. ... I don't mean like "Oh, get over it, it's in the past, it happened," but moving together as one sort of like.

\section{DISCUSSION}

Overall, our interviews suggest that the participants had a tacit understanding that the processes of reconciliation and forgiveness are negotiated in that, in general, an apology would be one gesture that would allow the stalled process of reconciliation to move forward. They see this apology needing to come from the Prime Minister for it to have formal meaning and strength and be representative of the nonindigenous community. However, such an apology does not remove the need for other powerful key social institutions, such as churches and the police, that were involved in past offenses against indigenous people to apologize also. The participants saw the value of an apology more in terms of the need for White people to have a better knowledge and understanding of the issues than for Black people to experience emotional support and healing. Thus, as well as stressing the need for sincerity in an apology, participants indicated that the apology needs to be based on a clear understanding of the background and issues. According to participants' responses, the function of an apology would be to set the record straight and 
allow White people to gain greater awareness of themselves and a better appreciation of their position of power. This is consistent with Holt's (personal communication, July 2003) proposed fourth stage of the relationship between indigenous and nonindigenous Australians.

Although the participants recognized that the population as a whole includes more recent immigrants and not just the descendents of British settlers, there was a lack of clarity about where more recent immigrant groups fit into the apology-forgiveness-reconciliation process.

In the context of the process of negotiated forgiveness, these interview data are very informative. The issue of forgiveness did not arise spontaneously in the interviews, suggesting that, at this point, forgiveness may not be of the most salience to the indigenous population. Even when asked directly about what is needed for indigenous people to be able to forgive nonindigenous people, the participants tended to have little to say. They either referred to the need for an apology or to the need for nonindigenous people to be more aware of the history of oppression and dispossession, or they passed over the issue. Forgiveness and eventually reconciliation may therefore be somewhat more distant than proximate. There is more work to be done by both the nonindigenous and indigenous populations, but how this is to be done remains a complex question. On the basis of Haber's (1991) argument, expecting Aboriginal people to consider forgiveness is tantamount to asking them to stop seeing non-Aboriginal people as they are presently seen and to begin affirming their self-worth. Such a request may be insensitive and unrealistic. As Andrews (2000) cautioned, there is no moral obligation on the victims' part to offer forgiveness, even if an apology is given. They may, for a variety of reasons related to the nature and extent of the violations against them, be unwilling and unready to do so.

Hartwell (1999) reminded us that forgiveness is a complex and prolonged evolutionary process, interwoven with justice, apology, truth, and reconciliation. Further, the root emotion of forgiveness is anger, in that it is the expression of righteous anger and indignation, according to Tavuchis (1991), which prompts the necessity for an apology, the driving force behind forgiveness. Mediating this process though is the experience of genuine regret (Tavuchis, 1991) or embarrassment (Scheff, 1994) on the part of the perpetrator of violence. It is pertinent that the righteous anger and indignation of indigenous Australia have only recently begun to be expressed in a unified, national manner and to be heard by the mainstream. The Stolen Generations inquiry gave voice to those who have not been listened to or have not had the language in which to tell their story (Frow, 1998). The style adopted by the Inquiry, the evidence provided, and the subsequent report and its associated publicity gave legitimacy to the expression of anger. However, Leigh (2002) suggested that movement toward reconciliation will require shifting nonindigenous Australians out of their comfort zone, and it is possible that, so far, the indigenous story may have lacked the force necessary to trigger the required level of discomfort, regret, or embarrassment. 
An alternative, perhaps more forceful pathway to potential reconciliation is evident in the many "truth commissions" established around the world over the past three decades. The best known of these is the South African Truth and Reconciliation Commission. Not only did this Commission hear the stories of those whose human rights had been violated, it provided an official forum for many of those who had perpetrated the violations to make full disclosures, to offer a sincere apology, and to seek amnesty. The final report of the Commission (1998) indeed documented cases of victims who forgave their perpetrators. The immense publicity afforded to the Commission through its televised hearings helped to collectivize individual suffering and enabled the construction of the notion of "national victim" (Wilson, 2000). Although the Commission has been criticized for various reasons (e.g., Allan, 2000), according to Bertelsen (1998) this outcome destabilized the identity of many South Africans, both Black and White. In Norval's (1999) terms, it "put into question sedimented identities, and opened them up for rearticulation." (p. 500). This opened the possibility for alternative futures to be considered.

Avruch and Vejarno (2001) pointed out that the majority of truth commissions have been implemented in countries in which there are transitional governments or emerging or fragile democracies driven by previously suppressed majorities. Such is not the case in Australia, where the government is stable and the violated group is by far in the minority. This has reduced the perceived need for a deeper analysis of, and response to, the past. There have been ad hoc apologies by various groups and institutions, but, as our participants pointed out, although these apologies are appreciated, it is the absence of an official apology and formal or structured process that is lacking. Without this, the reconciliation endeavor would seem bound to stagnate.

The sample size in our study was small, but the data are presented in the context of a preliminary phenomenological study of the indigenous Australian perspective on the issue of apology, forgiveness, and reconciliation. Therefore, we do not represent our findings as typical or representative of the diverse indigenous population in Australia. However, we do suggest that our data demonstrate some of the thinking on these issues that will need to be incorporated into a wider discussion of reconciliation.

\section{CONCLUSION}

The groundwork for negotiated intergroup forgiveness in Australia is an apology by nonindigenous Australia for the past oppression of and violence toward her indigenous peoples. An appropriate apology has "the power to form and reform what and who is considered to be legitimate within the reconstituting national imaginary. It is an utterance, therefore, which has immense potential as a redistributive force, both material and symbolic" (Gooder \& Jacobs, 2000, p. 231). Until such an 
apology is forthcoming, however, it is premature to talk about forgiveness, and the reconciliation process will remain stuck on the horns of a dilemma.

\section{BIOGRAPHICAL NOTES}

David Mellor is an associate professor in the School of Psychology at Deakin University in Melbourne, Australia. He is a trained clinical psychologist and has worked extensively in the child and family area. He also spent 2 years working with Aboriginal populations in the far north of Western Australia. From this clinical work he became interested in racism and has undertaken both quantitative and qualitative research in Sweden and Australia in this area. He has presented many papers at international conferences on this research and has several publications in press. His interest in reconciliation between indigenous and nonindigenous Australians and peace psychology has grown out of this work.

Di Bretherton has recently retired from the role of Director of the International Conflict Resolution Centre at the University of Melbourne. Over the past decade, among her numerous activities, she has engaged in partnerships with Aboriginal people on various research projects and run Australians for Reconciliation Study Circles. She held the position of Chair of the Committee for the Psychological Study of Peace of the International Union of Psychological Science for many years. In her retirement she is an Honorary Principal Researcher and associate professor at the Department of Psychology, University of Melbourne; Visiting Professor at the Australian Centre for Peace and Conflict at the University of Queensland; and Visiting Professor at the Zhou En Lai School of International Relations at the University of Nankai, Tianjin, China.

Lucy Firth is an economist who has worked in a variety of settings, including Aboriginal communities and the United Nations. Her recent research has focused on the impact of technologies on individuals, cultures, and economies. In particular, she is investigating the potential for information and communications technologies to build clinical capacity in underdeveloped and underserved communitiestypically in developing nations. She has recently taken up a senior position in the Northern Territory Health Department in Australia and holds an Honorary Research position with of the University of Melbourne.

\section{REFERENCES}

Allan, A. (2000). Truth and reconciliation: A psycholegal perspective. Ethnicity and Health, 5, 191-204.

Andrews, M. (2000). Forgiveness in context. Journal of Moral Education, 29, 75-86. 
Australian Bureau of Statistics. (2001). The health and welfare of Australia's Aboriginal and Torres Strait Islander peoples. Canberra: Australian Government Publishing Service.

Australian Bureau of Statistics. (2002a). 2001 Census: Basic community profile and snapshot. Canberra: Australian Government Publishing Service.

Australian Bureau of Statistics. (2002b). Prisoners in Australia, 2001. Canberra: Australian Government Publishing Service.

Australian Bureau of Statistics. (2002c). Schools in Australia. Canberra: Australian Government Publishing Service.

Avruch, K., \& Vejarno, B. (2001). Truth and Reconciliation Commissions: A review essay and annotated bibliography. Social Justice: Anthropology, Peace, and Human Rights, 2, 47-108.

Bertelsen, E. (1998). Ads and amnesia: Black advertising in the new South Africa. In S. Nuttall \& C. Coetzee (Eds.), Negotiating the past: The making of memory in South Africa (pp. 221-241). Cape Town, Western Cape Province, South Africa: Oxford University Press.

Bretherton, D., \& Mellor, D. (2006). Reconciliation between Aboriginal and other Australians: The "Stolen Generations." Journal of Social Issues, 62, 81-98.

Brush, B. L., McGee, E. M., Cavanagh, B., \& Woodward, M. (2001). Forgiveness: A concept analysis. Journal of Holistic Nursing, 19, 27-41.

Colaizzi, P. F. (1978). Psychological research as the phenomenologist views it. In R. S. Valle \& M. King (Eds.), Existential-phenomenological alternatives for psychology (pp. 48-71). New York: Oxford University Press.

Cunneen, C., \& McDonald, D. (1997). Keeping Aboriginal and Torres Strait Islander people out of custody: An evaluation of the implementation of the recommendations of the Royal Commission into Aboriginal Deaths in Custody. Canberra: Office of Public Affairs.

Dudgeon, P., \& Oxenham, D. (1989). The complexity of Aboriginal diversity: Identity and kindredness. Black Voices, 5, 22-39.

Enright, R. D., \& the Human Development Study Group. (1991). The moral development of forgiveness. In W. Kurtines \& J. Gerwitz (Eds.), Dimensions of forgiveness: Psychological research and theological perspectives (pp. 139-161). Radnor, PA: Templeton Foundation Press.

Enright, R. D., \& the Human Development Study Group. (1994). Piaget on the moral development of forgiveness: Identity or reciprocity? Human Development, 37, 63-80.

Enright, R. D., \& Zell, R. L. (1989). Problems encountered when we forgive one another. Journal of Psychology and Christianity, 8, 52-60.

Finch, J. (1993). "It's great to have someone to talk to": Ethics and politics of interviewing women. In M. Hammersley (Ed.), Social research: Philosophy, politics and practice (pp. 166-180). Thousand Oaks, CA: Sage.

Frow, J. (1998). A politics of stolen time. Meanjin, 57, 351-367.

Gooder, H., \& Jacobs, J. M. (2000). On the border of the unsayable: The apology in postcolonizing Australia. Interventions, 2, 229-247.

Green, N. (1995). The Forrest River massacres. South Fremantle, Australia: Fremantle Arts Centre Press.

Haber, J. G. (1991). Forgiveness. London: Rowman \& Littlefield.

Hartwell, M. B. (1999). The role of forgiveness in reconstructing society after conflict. Journal of Humanitarian Assistance. Available at http://www.jha.ac/articles/a048.htm

Human Rights and Equal Opportunity Commission. (1997). Bringing them home: National inquiry into the separation of Aboriginal and Torres Strait Islander children from their families. Canberra: Australian Government Publishing Service.

Hunter, E. (2000). Unmet need in indigenous mental health. In G. A. Andrews \& S. Henderson (Eds.), Unmet need in psychiatry (pp. 356-362). Cambridge, England: Cambridge University Press. 
Kaminer, D., Stein, D. J., Mbanga, I., \& Zungu-Dirwayi, N. (2001). The Truth and Reconciliation Commission in South Africa: Relation to psychiatric status and forgiveness among survivors of human rights abuses. British Journal of Psychiatry, 178, 373-377.

Keating, P. (1992, December). Australian launch of the International Year for the World's Indigenous People. Speech delivered in Redfern Park, Sydney. Available at http://www.aph.gov.au/senate/committee/ntlf_ctte/report_16/report/contents.htm

Leigh, A. K. (2002). Leadership and Aboriginal reconciliation. Australian Journal of Social Issues, 37, 131-151.

McClernon, F., Cairns, E., Lewis, C. A., \& Hewstone, M. (2003). Memories of recent conflict and forgiveness in Northern Ireland. In E. Cairns \& M. D. Roe (Eds.), The role of memory in ethnic conflict (pp. 125-143). London: Palgrave Macmillan.

McCullough, M. E., Pargament, K. I., \& Thoresen, C. E. (2000). Forgiveness: Theory, research, and practice. New York: Guilford.

Mellor, D. (2003). Contemporary racism in Australia: The experience of Aborigines. Personality \& Social Psychology Bulletin, 29, 474-486.

Mellor, D. (2004). Responses to racism: A taxonomy of coping styles used by Aboriginal Australians. American Journal of Orthopsychiatry, 74, 56-71.

Mellor, D., \& Bretherton, D. (2003). Reconciliation between Black and White Australia: The role of social memory. In E. Cairns \& M. Roe (Eds.), Memories in conflict (pp. 37-54). London: Palgrave Macmillan.

Nobles, W. W. (1980). Extended self: Rethinking the so-called Negro self-concept. In R. L. Jones (Ed.), Black psychology (2nd ed., pp. 99-105). New York: Harper and Row.

Norval, A. (1999). Truth and reconciliation: The birth of the present and the reworking of history. Journal of South African Studies, 25, 499-519.

Poole, R. (1999). Nation and identity. London: Routledge.

Reynolds, H. (2001). An indelible stain? The question of genocide in Australia's history. Ringwood, Victoria, Australia: Penguin.

Robson, C. (1993). Real world research: A resource for social scientists and practitioner-researchers. Oxford, England: Blackwell.

Scheff, T. J. (1994). Bloody revenge, emotions, nationalism, and war. Boulder, CO: Westview.

Shriver, D. W., Jr. (1995). An ethic for enemies: Forgiveness in politics. New York: Oxford University Press.

Smedes, L. B. (1998). Stations on the journey from forgiveness to hope. In E. L. Worthington (Ed.), Dimensions of forgiveness: Psychological research and theological perspectives (pp. 341-354). Radnor, PA: Templeton Foundation Press.

Tavuchis, N. (1991). Mea culpa: A sociology of apology and reconciliation. Stanford, CA: Stanford University Press.

Truth and Reconciliation Commission of South Africa. (1998). Truth and Reconciliation Commission of South Africa Report. Cape Town, Western Cape Province, South Africa: Author.

van Krieken, R. (1999). The barbarism of civilization: Cultural genocide and the "stolen generations." British Journal of Sociology, 50, 297-315.

White, J. P., \& Mulvaney, D. J. (1987). How many people? In D. J. Mulvaney \& J. P. White (Eds.), Australians to 1788 (pp. 113-117). Sydney, Australia: Fairfax, Syme and Weldon.

Wilson, R. A. (2000). Reconciliation and revenge in post-Apartheid South Africa-Rethinking legal pluralism and human rights. Current Anthropology, 41, 75-98.

Windschuttle, K. (2002). The fabrication of Aboriginal history: Volume 1. Van Dieman's Land 1803-1847. Paddington, Australia: Macleay.

Worthington, E. L. (1998). The pyramid model of forgiveness: Some interdisciplinary speculations about unforgiveness and the promotion of forgiveness. In E. L. Worthington (Ed.), Dimensions of 
forgiveness: Psychological research and theological perspectives (pp. 107-138). Radnor, PA: Templeton Foundation Press.

Yarwood, A. T., \& Knowling, M. J. (1982). Race relations in Australia: A history. Sydney: Methuen Australia. 